DOI https://doi.org/10.32841/2409-1154.2021.47-3.24

\author{
Denysiuk Yu. I., \\ Candidate of Philological Sciences, \\ Associate Professor at the Department of English Language and Military Translation \\ Hetman Petro Sahaidachny National Army Academy
}

\author{
Samoilova Yu.I., \\ Candidate of Pedagogy Sciences, \\ Associate Professor at the Department of Humanities \\ Sumy Branch of Kharkiv National University of Internal Affairs
}

\title{
THE METHODS OF LEXICAL AND LEXICO-GRAMMATICAL TRANSFORMATIONS IN THE FIELD OF MILITARY TRANSLATION
}

Summary. The article is devoted to the lexical features of the certain military terms translation related to weapons and tactics in accordance to national standards of the naming the armed forces and the linguistic support. During our research we used: an observation method to gather the necessary information of using the military terms in different countries, including ones which belong to different military manualssuch as Field Manual 101-5-1, Field Manual 3-21.8 (FM 7-8), Field Manual 6-0. and so on ; descriptive method for collecting and systematizing information on the problem of defining a term as a language unit and the military terminology system as an object of linguistic research; the method of information accumulation to form a bank of similar examples; method of semantic analysis to determine the features of the semantics of military terminology; structural and typological methods for determining the structural features of military terminology in English; method of translation analysis to determine the equivalence of translation reproduction of military terminology and taking into account the structure and semantics of terminology in the military field; methods of analysis and synthesis to determine the correct match for the compound terms depending on the methods of translatio; etc. In the military sphere transcoding (transcription and transliteration) as a method of lexical transformations means translation techniques in which the sounds and letters of the target language are transmitted sounds and letters that make up the tokens of the source language, for example: adaptive - adaptive, cognitive - cognitive; conflict - conflict. Calque is the reproduction of the combinatorial syllable of a word or phrase, in which the constituent parts of a word (morpheme) or phrase (token) are translated by the relevant elements of the target language, followed by the composition of the translated parts without any changes.

This research has practical value that an attempt has been made to analyze the Ukrainian translation of English military vocabulary and the present research can serve as a practical and theoretic basis for further researches in the military field, as well as contribute to the standardization of up-to-date English-Ukrainian military vocabulary.

Key words: military terminology, lexical transformation, grammatical transformation, descriptive translation, loan translation (calque), transcoding.

Introduction. The practice of military translation remains only to a limited circle of people, for military translators in the first place. The crucial component of military translation lies in providing the linguistic support of the Ukrainian Armed Forces during the events of international military cooperation, since such events require professional translation support. Professional translation supports of such events as peacekeeping and anti-terroristic operations as well as multinational military training depend on stable military terminology, military specific language training, as well as research activity in these directions.

Authors of one of the first military translation manuals Yu. Spazhev and A. Philipov view military translation in two aspects: as practical linguistic activity and and as an educational subject. Military translation as an area of practical linguistic activity is one of the types of special translation, with various military documents as its object. The relevancy of the military translation as a separate discipline is proved by the authors that present the list of peculiarities of oral and written military themed linguistic activity, which belongs to the military field as a separate field of knowledge. In some cases, there are so many peculiarities that it is extremely hard for the unprepared person to understand them (both Russian and anglophone in comparison with the Ukrainain language) (translated by $Y u$. D.) [1, p. 15].

In the field of military translation the first scholarly work belongs to V. Balabin, who researched the translation peculiarities of American military slang. V. Balabin started the series of translation studies researched of military sublanguage. He was also the first one to express the idea of creating the national school of military translation. The idea was the following: to provide quality training of professional translators in Ukraine, the one that would integrate the best accomplishments of modern philologic and other humanitarian sciences, and introduce those accomplishments into the educational process [2, p. 22].

The co-authorship of V. Haponova, I. Yaremchuk, I. Bloshchinskii have created the textbook "Military translation". O. Hukova has designed the textbook of practical course of military specific language training for higher education establishment.

Our research has been taken from real life translating or interpreting practice or from the materials, used as a reference for the teaching of Ukrainian military with the aim of strengthening its NATO interoperability as well as its defense capabilities.

The aim of the research is to study Lexical methods of translation of the military terminology.

Generally, when translating military terms, the following methods are most commonly used: descriptive translation, loan 
translation (calque), transcoding (transcription and transliteration), lexico-semantic and lexico-grammatical substitutions.

S. Yanchuk further extends the methods of translation and singles out:

- description of the meaning of the Anglophone term, e.g. voluntary contribution-in-kind - добровільний внесок не у грошовій формі (безоплатний внесок у справу підтримання миру, який може здійснюватися шляхом безкоштовного наданя державами військового персоналу у розпорядження Департаменту операцій із підтримання миру);

- loan translation (calque), e.g. small arms and light weapons (SALW) - стрілецька зброя і легкі озброєння (СЗЛО);

- partial or full transliteration, e.g. Eurocorps / European Corps - Єврокорпус / Європейський корпус, politicide політіцид;

- concretization of the word's meaning and by combined transcoding, e.g. jihadist - джихадист;

- loan translation (calque) or by meaning extension, e.g. Spot Report (SPOTREP) - термінова доповідь 3 місця події; line of contat - лінія бойового зіткнення [3, p. 56].

Ukrainian Translation Studies scholar I. Korunets' defines the kind of major or minor alterations in the structural form of language units performed with the aim of achieving faithfulness in translation as translator's transformations [4, p. 361].

Thus, the translator is mostly free to deliberately choose any sense unit of any structural form in order to convey faithfully the meaning of the source language unit. The choice of the equivalent is conditioned by the personal preference and by the context requiring correspondingly more or less extended information of the reader about some specific cultural notion. Therefore, the translator's individual style is realized mainly through the selection of specific language means.

The structure of the Ukrainian sentence can totally differ from the structure of the English sentence. This means that the translated text undergoes various changes or so called transformations, which is indispensable in every translation let alone the case with audiovisual translation. It is not uncommon for the text to have a totally different word order or clauses. In many cases, parts of speech in English can be replaced by other parts of speech in Ukrainian. Such is the case with lexical-semantic replacement or substitution. Replacement is the most widely-spread type of translational transformations. It can affect any kind of linguistic units: word forms, parts of speech, sentence elements, types of syntactic relations and sentence types. Replacement is a transference of an idea expressed by a definite grammatical category of the SL (source language) by a different grammatical category of the TL (target language).

V.N. Komissarov identifies three groups of translation transformations: two basic: lexical and grammatical and one complex - lexico-grammatical. Lexical transformations include: transcoding (transcription, transliteration); loan translation (calque); lexico-semantic substitution (concretization, generalization, modulation). Grammatical transformations include techniques of literal translation, grammatical replacement (replacement of word forms, parts of speech, part of the sentence). To lexico-grammatical transformations, V.N. Komissarov includes antonymic translation, explication (descriptive translation) and compensation [4, p. 38].

The main contribution of this research resides in combining not only empirical and pragmatic analysis with the intention of deriving norms or recurring patterns in the translation process, but also casting light on the problem of graphical and parametrical representation for the translation method. Thus, we postulate that the translation method can be represented as a combination of the empirical and pragmatic analysis with the graphical and parametrical representation, which, of course, have to be taken into account for the preliminary phase of translation as well as for the translation phase itself.

We have selected the brightest examples from professional notes, created thoroughout the time of 5 years of translating and interpreting and teaching in the military field. The subject of the research is various methods of translating military terminology. In this article we'll speak about Lexical transformation which includes transcoding (transcription, transliteration) and loan translation (calque).

Main body. Transcoding presupposes the transfer of foreign realities by reproducing the forms of its expression using letters of the Ukrainian alphabet. Transcription reproduces the sounding and transliteration reproduces the graphic form: Captain - кептен; Commander - командер. The example of combined transcribing and transliteration is Warrant officer- - уорент-офіцер; the examples of transliteration: Master sergeant - майстер-сержант; Serjeant major - сержант-майор.

Oftentimes, transcoding is combined with literal translation. Have a look at the exapmles of transcription combined with literal translation: Tracer - трасер, трасуючий боєприпаси. The word tracer is usually translated as "трасуючий боєприпас". However, in the military environment, tracers are often referred to as "трасери", due to the shortness and, thus, conveniency of the word. The same idea applies to the example as MILES (Multiple Integrated Laser Engagement System) - МАЙЛС (комплексна лазерна система імітації бою). Identical situation is with translateration combined with literal translation: Chief master sergeant - головний майстерсержант; Command sergeant-major - головний сержант-майор. Yet another example is transcription combined with modulation: Claymore - міна-пастка “клеймор".

Transcoding has its advantages and disadvantages. The advantage is clear: the form of the written word is not violated; however, the disadvantage is that target readers may be unsure about the pronunciation or even the meaning of the transcribed word. In the military sphere, however, transcoding of the ranks is a common case and is popular thanks to its brevity.

Calque is one of the most common methods of rendering military vocabulary. It re-establishes the semantics and the structure of the original word by means of the native language. In other words, it is the reproduction of not phonetic but combinatory structure of the word, when morphemes of lexemes are translated with the help of corresponding parts of the target language. Calque as a method of translation became the reason of numerous borrowings in the intercultural communication, when transliteration or transcription was unacceptable for aesthetic or notional reasons. In our research paper, this translation method is illustrated with the following examples: Air assault operations - повітряно-штурмові операціі; Air assault task force - десатнто-штурмова тактична група; Assault fire team - штурмова група; Attack by fire - обстрілювати; Avenues of approach-шляхи підходу; Back blast-зворотня вибухова хвиля; Battlefield - поле бою; Conducting resupply patrol - проведення операцій з постачання, організація постачання на вантажному автомобілі; Concurrent training - паралельне тренування. In the military environment concurrent training happens parallel to 
the main training event. It is often referred to by the Ukrainian military as "супутні тренування"; Cover and concealment - укриття та прикриття. Cover and concealement are one of the terms that need to be analyzed thoroughly before translating. To provide an equivalent translation, we need to define what cover and concealment both mean. Using professional notes created throughout the time span of 5 years of translating and interpreting and teaching in the military field to define cover and concealement; we learn that cover is "protection from the fire of hostile weapons. Concealment is protection from observation. Good cover will ideally reduce the available space for an attacker to make contact with weapons (firearms or otherwise). Materials such as steel, concrete, water, packed earth, and thick wood all make great resources for cover. Good concealment will ideally allow you to observe your enemy without him (or her, or them) being able to readily observe you back. Elements like foliage, netting, shadows, fabric, and nonreflective surfaces can all make for a great basis for concealment". The Dictionary of Ukainian Language defines the word "укриття" as "спеціальна споруда, окоп і т. ін., зроблені для захисту людей, техніки від бомб, снарядів тощо". The word "прикриття" is defined as both "захисне місце, схованка" and "те, що робить непомітним, невидним що-небудь", which means that the word "прикриття" can be used to denote both cover and concealement. Also, the word cover and its correspondent "прикриття" both have another meaning, which is "захист кого-, чого-небудь в бою", for example "Підтримка i прикриття наших військ 3 повітря покладались на авіацію 2-ї і 5-ї повітряних армій". The translation choice "укриття" for cover and "прикриття" for concealement is made in order to reproduce the collocation and draw a line between these two notions. This distinction is required in Ukrainian, due to the difference of the notions. If the polysemous word "прикриття", which has at least three military related meanings, will be used for both cover and concealement, confusion is likely to appear. Military field, naturaly, is the last place where confusion is tolerated.

Some other examples of calque are: Danger close - небезпечне наближення; Designated area - визначений район; Dry fire “стрільба в суху” (імітаційна стрільба з пустим патронником); Fire power - вогнева міць; Fire planning - організація вогню; Fire team, support by fire team - група вогневої підтримки, бойова група, вогнева група; Fire team bounding - перебіжки вогневих груп; Ilovaysk pocket - іловайський котел; Issue the warning order довести попередній наказ; Laser rangefinder-лазерний далекомір; Most Likely Avenue of enemy Approach/Retreat - найімовірніший напрям підходу/ відходу противника; To shift fire - змістити вогонь; To lift fire - 1) перенеси вогонь в глибину; 2)припинити вогонь; To cease fire - припинити вогонь. Three last examples are of special interest. When interpreting discussions about tactical operations, at some point it focuses on "how to control direct fires used to suppress the enemy on the objective (OBJ) while an assault element maneuvers to secure a foothold like an obstacle breach or a building entry". There have been a number of situations where speakers have used the terms to lift fire and to cease fire interchangeably, using yet another term - to shift fire, which reqired explicitation on their part in order for the interpreter to chose the correct translation solution. Usually the two terms shift and lift fire are used during a squad attack when the assaulting team is maneuvering through the enemy position. The meaning of these two expressions is the following: shift fire means exactly how it sounds. When directed, the shift fire command is meant to move a concentration of fire from one point to another, usually from right to left or vice versa. Lift fire has two meanings. Meaning
№1 that can be found in Field Manual 101-5-1 is the following: "In direct fire, the command to raise the cone of fire so that the beaten zone strikes the target, but the space between the target and the firing weapons is safe for maneuver by friendly forces" [5, p. 97]. The Ukrainian correspondent is “перенести вогонь в глибину”. Another meaning can be found in FM 3-21.8 The Infantry Rifle Platoon and Squad. Table A-7 states that when directed to lift fire you cease all fire onto objective, maintain overwatch and scan objective until told to reengage or go out of action. For example, "The support element lifts fire once the assault element has secured BLDG\#1 (building 1) and signals with a white star cluster. Once signaled, the Support element is to observe the western portion of OBJ WOLF vic. TRP001 for enemy activity". There is no other definition for lift fire in this FM [6]. However, the FM 101-5-1 was replaced by FM 1-02 in 2003 and is now again replaced with ADP/ADRP 1-02, dated 2012-2013 and it doesn't show anything on lift fire. Having consulted with the professional military representatives multiple times, the conclusion has been made that the term lift fire should be translated only after the analysis of the context, since the first meaning is "continue shooting" an the second meaning is "stop shooting". If lift and cease fire are used to describe the same action, confusion is likely to result during execution in both Ukrainian and English languages. This is why, in the English-speaking military field the term lift fire is often avoided, in order to minimize the confusion. If case the term is used, the context will play the determining part and the meaning of the term should be either figured out on the context, or better double-checked with the speaker.

Lastly, we would like to dwell on the word formations and its collocations. The first pair is: Combat formation - бойовий порядок; and March formation - похідний порядок or передбойовий порядок. In case of the latter translation choice, the translation technique applied is modulation. Furthermore, combat formations are subdivided into: Column formation (for vehicles) - бойовий порядок "колона"; and File formation (for personnel) - бойовий порядок "колона".

Even though the translation choice "бойовий порядок колона" in Ukrainian applies to both dismounted and mounted personnel, in the English language there is a differentiation between column and file formation, with the former denoting the formation of the vehicles and the latter denoting the formation of the personnel: "Herringbone" formation - бойовий порядок "ялинка"; "Wedge" formation - бойовий порядок "клин". While the "Herringbone" formation illustrates that the translation choice is calque, example "Wedge" formation illustrates that there are two different notions that exist in two different cultures and thus, the translation required adaptation. While the translation choice could have stopped at the literal translation "хребет оселедця", the variant "бойовий порядок ялинка" is more acceptable since the herringbone resembles the pattern of the firtree pattern in Ukrainian culture. The translation choice "бойовий порядок ялинка" sounds far more natural and familiar.

All in all, we can see that literal translation, apart from being commonly applied in the military translation in order to produce the equivalence effect in the target culture, in some cases requires lexico-semantic as wel as lexico-grammatical transformations such as modulation, concretization, generalization, explication, etc.

Conclusions. As we can see, successful military translation often requires not only profound linguistic competence, but also understanding of the military field, supported by constant inquiring 
and unlimited attention to detail. Furthermore, a military translator and especially interpreter should have perfect memory, due to the abundance of shortenings, abbreviations and acronyms in the military filed.

Thus, this research has practical value that an attempt has been made to analyze the Ukrainian translation of English military vocabulary and the present research can serve as a practical and theoretic basis for further researches in the military field, as well as contribute to the standardization of up-to-date English-Ukrainian military vocabulary.

\section{References:}

1. Юндіна О. Теорія і практика військового перекладу в Україні. Цит. 2016, 16 березня. URL: http://papers.univ.kiev.ua/1/inozemna filologija/articles/yundina-o-theory-and-practice-of-militarytranslation-in-ukraine_14874.pdf, p.15.

2. Балабін В. Професійна компетентність військового перекладача. Мовні та концептуальі картини світу. 2002. № 7. С. 20-23.

3. Янчук С.Я. Особливості перекладу англомовної військової документації миротворчих місій ООН та НАТО. Київ : Логос, 2013. 220 с.

4. Корунець І.В. Вступ до перекладознавства : підручник. Вінниця : «Нова Книга», 2008. 512 с

5. Field Manual 101-5-1. Marine corps, p. 97. URL: http://tsg3.us/tnsg_ lib/unit_dig_lib/fm_101_5_1.pdf.

6. Field Manual 3-21.8 (FM 7-8). Infantry Rifle Platoon and Squad. Washington, DC, 28 March 2007. URL: https://https://www.utm. edu/departments/milsci/_pdfs/FM\%203-21.8_Infantry\%20 Rifle\%20 Platoon\%20and\%20Squad.pdf (Accessed 28 December 2020).

7. Field Manual 6-0. Military. Rehearsals. App. F. URL: https://www.globalsecurity.org/military/library/policy/army/fm/6-0/ appf.htm (Accessed 28 December 2020).

Денисюк Ю. І., Самойлова Ю. І. Методи лексичних і лексико-граматичних трансформацій у сфері військового перекладу

Анотація. Стаття присвячена лексичним особливостям перекладу певних військових термінів, що стосуються зброї та тактики, відповідно до національних стандартів іменування Збройних Сил і мовної підтримки. Під час нашого дослідження ми використовували: метод спостереження для збору необхідної інформації про використання військових термінів у різних військових статутах, включаючи ті, що належать до різних Військових статутів, таких як Польовий статут 101-5-1, Польовий статут 3-21.8 (FM 7-8), Польовий статут 6-0. і т. д.; описовий метод збору та систематизації інформації щодо проблеми визначення терміна як мовної одиниці та системи військової термінології як об'єкта лінгвістичних досліджень; метод накопичення інформації для формування словника з подібними прикладами вживання; метод семантичного аналізу для визначення особливостей семантики військової термінології; метод перекладацького аналізу для визначення еквівалентності відтворення перекладу військової термінології та врахування структури та семантики термінології у військовій галузі; методи аналізу та синтезу для визначення правильної відповідності складених термінів залежно від методів перекладу. Зроблено спробу проаналізувати особливість декількох методів перекладу військової термінології: транскодування як перекладацький метод, за якого за допомогою звуків і букв мови перекладу передаються звуки та букви, що складають лексеми вихідної мови, напр. adaptive - адаптивний, conflict - конфлікт; метод кальки як відтворення комбінаторного складу слова чи словосполучення, у якому складові частини слова (морфема) або словосполучення (лексема) перекладаються відповідними елементами мови перекладу.

Це дослідження має практичну цінність, оскільки була зроблена спроба проаналізувати український переклад англійської військової лексики, та може бути практичною та теоретичною основою для подальших наукових досліджень у військовій галузі, а також сприяти стандартизації вдосконалення сучасного англо-українського військового словника.

Ключові слова: військова термінологія, лексична трансформація, граматична трансформація, описовий переклад, калька, перекодування. 